\title{
Endocardial silicone lead wear: description of tribological phenomena on the basis of microscopic examination of removed leads. Preliminary report
}

\author{
Barbara Małecka ${ }^{1}$, Andrzej Ząbek ${ }^{2}$, Andrzej Ciaś3 ${ }^{3}$, Janusz Stępiński ${ }^{3}$, Andrzej Kutarski ${ }^{4}$, Jacek Rońda ${ }^{5}$, \\ Jacek Lelakowski ${ }^{1}$, Janusz Małecki ${ }^{6}$ \\ 'Department of Electrocardiology, Institute of Cardiology, Jagiellonian University Medical College, John Paul II Hospital, Krakow, Poland \\ ${ }^{2}$ Department of Electrocardiology, John Paul II Hospital, Krakow, Poland \\ ${ }^{3}$ Faculty of Metals Engineering and Industrial Computer Science, Department of Physical Metallurgy and Powder Metallurgy, \\ AGH University of Science and Technology, Krakow, Poland \\ ${ }^{4}$ Department of Cardiology, Medical University, Lublin, Poland \\ ${ }^{5}$ Faculty of Metals Engineering and Industrial Computer Science, Department of Applied Computer Science and Modelling, \\ AGH University of Science and Technology, Krakow, Poland \\ ${ }^{6}$ Outpatient Clinic, Medical Private Practice, Krakow, Poland
}

\begin{abstract}
Background: The passage of a lead in tissues and in the cardiovascular system depends on the implantation technique. The structure of the leads, which is a combination of two or more materials, triggers their wear. Breakage of the external pacemaker (PM) lead insulation causes unsealing of the lead and exposure of its internal spaces, which can be the anchor of lead-dependent infective endocarditis (LDIE). In the case of implantable cardioverter-defibrillator (ICD) leads, damage to external insulation is the cause of externalisation of the cable.

Aim: To describe endocardial lead abrasion as a tribological phenomenon resulting from rubbing the leads against each other in the mechanism of polymer on polymer friction, and other mechanisms associated with lead structure i.e. polymer on metal friction.

Methods: Twenty-two leads were extracted from ten patients (three women) aged $66.5 \pm 13.4$ years. In all cases, the reason for lead removal was infection - in $80 \%$ LDIE. The PM (one ICD) two- and three-lead systems, all with silicone insulation, were aged 3-25, mean 8.3 years. The destroyed polymer insulation was examined by optical and scanning electron microscopy. The site of damage was defined as the length of the lead from its distal end. This lead segment motion was analysed on chest scopy performed prior to the removal procedure. In this way, three sites of lead damage were distinguished: intracardiac, intravenous, and intrapocket. Tribological wear was observed on the polymer-metal interface and between the leads. The following characteristics were recorded: the type of PM or ICD system in which the extracted leads worked, the lead dwell time, and the lead model.
\end{abstract}

Results: Scanning electron examinations showed that in all cases lead insulation had undergone tribological failure. In all samples, the image of fatigue wear was recorded. In all examined places, we found evidence that adhesive wear was present with the transfer of material to the edges of friction zones and/or to friction partners. In $80 \%$ of the patients with LDIE, a total breakage of insulation and abrasive wear was observed, especially when a lead cyclically bent and rubbed against another lead. Abrasive wear was the cause of lead unsealing at sites of strong lead bending, in the right atrium near the tricuspid valve. Conclusions: Acknowledging the tribological mechanism may connect the commonly known crush syndrome with lead abrasion in the cardiac implantable device pocket and in the heart cavity.

Key words: endocardial leads, tribological wear, silicone insulation

Kardiol Pol 2014; 72, 10: 960-968

\section{Address for correspondence:}

Andrzej Ząbek, MD, MSc, Department of Electrocardiology, John Paul II Hospital, ul. Prądnicka 80, 31-202 Kraków, Poland, e-mail: andrzej_j_z@poczta.onet.pl Received: 06.08.2013 Accepted: 27.03.2014 Available as AoP: 29.04.2014

Copyright (C) Polskie Towarzystwo Kardiologiczne 


\section{INTRODUCTION}

Endocardial leads are built from metal wire or wires inserted inside polymer tubes which have the function of isolation [1]. A part of a lead from its connection with the pacemaker (PM) or implantable cardioverter-defibrillator (ICD) (later called cardiac implantable device - CID), up to the entrance to a vein runs in a soft tissue. Important aspects of this passage depend on the implantation technique. In the case of subclavian or axillary vein puncture, the lead passes through the muscles, and, in the tunnel created in this way it is more prone to counteraction of the neighbouring tissues. In contrast, in cephalic vein phlebotomy, the lead in the subclavian area is provided with additional protection by the vein wall and adventitia [2]. The proximal part of the lead rests in the CID pocket, most often on the surface of the pectoral muscle under the CID, in the form of loops made up of its excess length. A major part of the lead is situated in the cardiovascular system and its passage also depends on the implantation technique. This especially refers to lead loops in the heart cavity, as well as to contact between leads on their crossing. In the human body, leads must move and lead bending is forced by body motions. In the CID pocket and the tunnel leading to the vein, lead motion results from actions of the skeletal muscles during a patient's daily activities. The movement of the upper extremity on the CID implantation side causes bending of the lead on the clavicle and probably is the initial stage of crush syndrome [2, 3]. Pressing down on the CID pocket tissue, e.g. at night, causes bending of a lead on the edge of the can, and could initiate damage of the lead in the CID pocket [4]. At this point, the part of the lead left in the pocket and the manner of its looping may be significant. Lead bending in the heart cavities can occur on the tricuspid valve or on the loop of the second lead when there are more leads [5, 6]. Leads move with the rhythm of the heart even in the case of no activity of skeletal muscles. The part of a lead which is located in the vein passage is more stable than the part in heart cavities.

While assessing macroscopically and microscopically the condition of the leads, the breakage of silicone endocardial lead insulation in about $25 \%$ of leads removed transvenously was noticed [7]. Damage of lead insulation was observed when two or more leads were implanted into the cardiovascular system. Therefore, this phenomenon was initially assessed as the effect of lead friction in the heart rhythm. In this historic paper, lead abrasions on sites which had not been described earlier were presented. Analysis of tribological wear helps us to understand the mechanisms of lead damage.

Tribology is the science of interacting surfaces in relative motion. It includes the study of friction, lubrication and wear. The term "tribology" became widely used following the Jost Report in 1966 [8]. The word "tribology" is derived from Greek root of the verb "tribo = I rub" and the suffix "logy". Wear due to friction is called tribological wear [8]. Wear is a progressive loss of material from the surface due to abrasion, cracking and separation of large particles and adhesion of the interacting surfaces. Tribological phenomena occur on surfaces of endocavitary leads which after implantation in the human body have contact with other interacting surfaces of other leads, as well as with human tissues. Tribological phenomena also occur inside a lead, between its components.

In the present study, damage to removed endocavitary leads is analysed as tribological wear.

\section{METHODS}

Leads removed during consecutive transvenous lead extraction (TLE) procedures in the period December 2010 to March 2011 were qualified for the research. The leads had to fulfill the following criteria: (1) silicon isolation; (2) the absence of extraction damage which would make assessment of the condition of the insulation impossible; and (3) the presence of macroscopic and optical microscopic damage not connected with TLE. Damage connected with TLE has been described before [5, 9].

The reasons for lead extraction were pocket infection (PI) and lead-dependent infective endocarditis (LDIE). PI was defined as an infection limited to the pocket of the CID with the presence of local signs of inflammation, including erythema, warmth, fluctuance, or erosion with purulent drainage. LDIE was defined as an infection extending to the leads, cardiac valve leaflets, or endocardial surface with vegetations visible in transoesophageal echocardiography and/or positive swabs from extracted leads.

Leads removed by mechanical Byrd dilators (Cook) were examined by optical and scanning electron microscopy (SEM) to evaluate wear mechanisms. The examined sites were: between the leads, polymer-metal interfaces, external and after cutting - internal insulation surfaces of the leads. Images of removed leads and of the same type of unused leads kept in the vacuum pocket were compared. The site of damage was defined as the length of the lead from its distal end. This lead segment motion was analysed on chest scopy performed prior to removal. The location of the lead damage site on chest radiography is described elsewhere [6]. In localising in this way the site of lead damage in each case, intracardiac, intravenous, and intrapocket regions were distinguished.

The type of the damaged sites observed in SEM was described using a code composed of two letters. The first position in the code refers to the continuity of silicone insulation (A - absence of unsealing; $\mathrm{P}$ - presence of unsealing), and the second position to abrasion and silicone transfer to edges of the friction zone with formation of silicone growth (A - absence of silicone growth; $\mathrm{P}$ - presence of silicone growth).

\section{Preparation for SEM}

Leads, kept in formalin, were rinsed in running water, then placed in ethyl alcohol, rinsed for 3 to 5 min using ultrasonic cleaner, and then dried. Before collecting samples for SEM, the whole lead was examined under an optical microscope so 


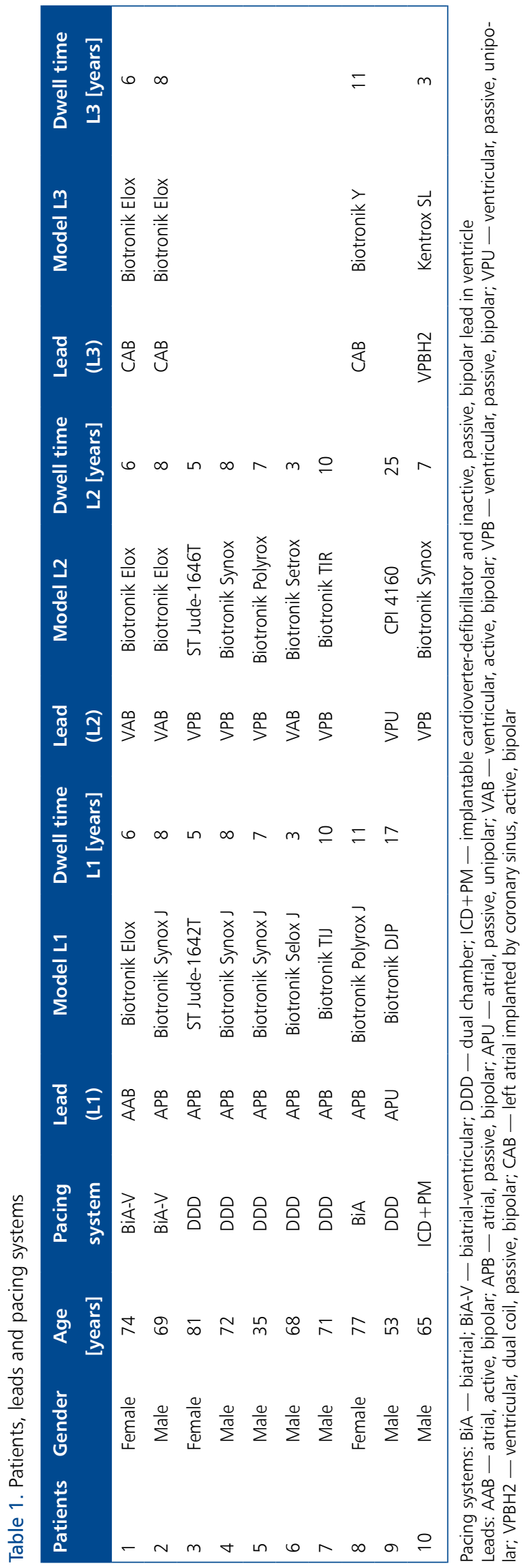

that the collected sample was not malformed by cutting and no damage was omitted. Samples 1 to $3 \mathrm{~cm}$ long were cut with a scalpel. Lead samples were mounted with the help of conductive graphite pads on a specimen stub and coated with a thin layer of gold, to improve conductivity of silicone insulation and increase the resolution of SEM. A Cambridge Stereoscan 120 SEM was used with accelerating voltage of $10 \mathrm{kV}$.

\section{Statistical analysis}

The data was evaluated using Statistica package version 10 (Stat Soft). For continuous variables, mean value and standard deviation were specified. For comparison of categorical variables, Pearson $\chi^{2}$ test was used, and for two-way tables a Fisher exact test. For multiple comparisons, Bonferroni correction was introduced. A $p$ value $<0.05$ was considered significant, but for multiple comparisons: $\mathrm{p}<0.0167$.

\section{RESULTS}

Twenty-two leads were extracted from ten patients (three women) aged $66.5 \pm 13.4$ years. The PM (one ICD) two- and three-lead systems, all with silicone insulation, were aged $3-25$, mean 8.3 years. The mean number of implanted leads per patient was 2.2. The mean number of procedures until TLE was 1.9, with the mean time from the last procedure until TLE 57.3 months. The details of lead models are recorded in Table 1. The reason for CID removal was infection in all cases - in 80\% LDIE and in the remaining 20\% PI. Analysis of photos taken with SEM from 37 damaged sites showed that lead insulation underwent tribological destruction in all cases (Table 2). The loss of lead isolation smoothness with local depletion of external silicon insulation most often appeared in the intracardiac region in the right atrium cavity (Fig. 1). In this region, in $80 \%$ of the patients with LDIE, total breakage of insulation with metal wire exposure was proved (Fig. 2). In the intrapocket region, silicon insulation damage without interruption of its continuity was observed in $60 \%$ of the cases (Figs. 3, 4). The presence of damaged sites was statistically significantly different in multiple comparisons with Bonferroni correction between the distinguished regions (60\% vs. $30 \%$ vs. $100 \%, p=0.0049$ ). The damaged sites appeared much more often in the intracardiac than in the intravenous region $(100 \%$ vs. $30 \%, p=0.0031)$. However, there was no statistically significant difference in the incidence of damage in the intrapocket and the intravenous regions (60\% vs. $30 \%$, $p=0.3698>0.0167)$, or in the intracardiac and the intrapocket regions $(100 \%$ vs. $60 \%, p=0.0433>0.0167)$. The image of the damage in the intrapocket region with silicon accumulation on the edges of the friction zone was different from the other two locations - when the blood rinses the leads (Table 2). The transfer of silicon to friction partner in the silicon-metal pair was noted at the site of lead bending in all cases (Fig. 3). In all samples, an image similar to fatigue wear was present. This also appeared opposite the site of 
Table 2. Indications for transvenous lead extraction (TLE) and types and number of lead damages

\begin{tabular}{|c|c|c|c|c|c|c|c|}
\hline \multirow[t]{2}{*}{ Patients } & \multirow[t]{2}{*}{$\begin{array}{l}\text { Indications } \\
\text { for TLE }\end{array}$} & \multicolumn{2}{|c|}{$\begin{array}{l}\text { Damages in } \\
\text { intrapocket region }\end{array}$} & \multicolumn{2}{|c|}{$\begin{array}{c}\text { Damages in } \\
\text { intravenous region }\end{array}$} & \multicolumn{2}{|c|}{$\begin{array}{c}\text { Damages in } \\
\text { intracardiac region }\end{array}$} \\
\hline & & $\begin{array}{l}\text { Type of } \\
\text { damage }\end{array}$ & $\begin{array}{c}\text { Number of } \\
\text { damage sites }\end{array}$ & $\begin{array}{l}\text { Type of } \\
\text { damage }\end{array}$ & $\begin{array}{c}\text { Number of } \\
\text { damage sites }\end{array}$ & $\begin{array}{l}\text { Type of } \\
\text { damage }\end{array}$ & $\begin{array}{c}\text { Number of } \\
\text { damage sites }\end{array}$ \\
\hline 1 & LDIE & $1 \mathrm{AP}$ & 1 & $x$ & 0 & $2 \mathrm{PA}$ & 2 \\
\hline 2 & LDIE & $2 \mathrm{AP}$ & 2 & $x$ & 0 & $2 \mathrm{PA} ; 1 \mathrm{AA}$ & 3 \\
\hline 3 & LDIE & $1 \mathrm{AP}$ & 1 & $1 \mathrm{AA}$ & 1 & $1 \mathbf{P A} ; 1 \mathbf{A A}$ & 2 \\
\hline 4 & LDIE & $2 \mathrm{AP}$ & 2 & $x$ & 0 & $2 \mathbf{P A} ; 1 \mathbf{A A}$ & 3 \\
\hline 5 & LDIE & $2 \mathrm{AP}$ & 2 & $x$ & 0 & $2 \mathrm{PA}$ & 2 \\
\hline 6 & LDIE & $x$ & 0 & $x$ & 0 & $3 P A$ & 3 \\
\hline 7 & $\mathrm{Pl}$ & $3 \mathrm{AP}$ & 3 & $2 \mathrm{AA}$ & 2 & $1 \mathrm{AA}$ & 1 \\
\hline 8 & LDIE & $x$ & 0 & $1 \mathrm{AA}$ & 1 & $3 \mathbf{P A} ; 1 \mathbf{A A}$ & 4 \\
\hline 9 & $\mathrm{Pl}$ & $x$ & 0 & $x$ & 0 & $1 \mathrm{AA}$ & 1 \\
\hline 10 & LDIE & $x$ & 0 & $x$ & 0 & $1 \mathrm{PA}$ & 1 \\
\hline Total & & $6 / 10(60 \%)$ & 11 & $3 / 10(30 \%)$ & 4 & $10 / 10(100 \%)$ & 22 \\
\hline
\end{tabular}

LDIE — lead-dependent infective endocarditis; PI — pocket infection; type of damage shown as double-letters code: AP — absence of unsealing and presence of silicone growth; AA - absence of unsealing and of silicone growth; PA - presence of unsealing and absence of silicone growth; $\mathrm{X}$ - absence of damage

total silicon loss. In all examined places, silicone destruction probably due to adhesive wear was present with the transfer of material to the edges of friction zones and/or to friction partners. Abrasive wear was the most probable cause of lead unsealing at sites of strong lead bending, in the right atrium near the tricuspid valve (Fig. 5).

\section{Results commentary - tribological wear in description of removed leads}

The silicon leads were used for different periods of time, from three to 25 years. Silicon elastomers in high-consistency silicone rubber have always had a constant chemical composition and are characterised by stable chemical properties [10]. The changes in consecutive lead models due to the miniaturisation trend have resulted in silicon insulation thinning and to spatial linking of elastomers. The use of thinner and thinner silicon rubber has accelerated the process of lead unsealing as a result of tribological wear. According to the general rules of tribological wear, in the initial stage of destruction of silicone lead insulation, fatigue wear occurs [11]. This stage can be called the incubation, and varies in duration $[11,12]$. Fatigue wear is caused by cyclic bending of the lead that produces a deformation of insulation and internal stresses in its outer layer. Microscopic cracks appear in the silicone layers located near the surface due to this cyclic deformation in so called Bielayev's points. Micro cracks can coalesce during the deformation process and a 'macro crack' can form. Usually a macro crack propagates towards the surface, which could result in stratification and fragmentation of polymer insulation. Fatigue wear occurs also when the surface is smooth and adhesion can be eliminated [13]. It can appear in all parts of silicone insulation as a result of bending, even if the lead is not in contact with surrounding tissues, or with another lead, or with a CID can (Fig. 1). Adhesive wear is related to even short-term adhesion of surfaces remaining in contact, and increases in cases of surface roughness. Adhesive wear appears primarily from the adhesion of sliding surfaces. Contact of adhesive surfaces and friction produces local plastic strain and breaking of cohesive bonds, which usually leads to polymer pieces transfer to the surface of the friction partner [14]. The transfer of material always occurs from polymer of low adhesive energy density to that of higher cohesive energy density [11]. Polymer-non polymer adhesive wear, for dry sliding conditions, has been described in relation to implants [15]. This internal adhesive frictional contact of a metal wire and an internal layer of silicone insulation is dry from the moment of implantation until the moment of lead unsealing with inflow of blood or body fluids into lead internal space (Fig. 2). This contact is present on the entire lead length, but the sites of intense adhesion wear are the points where the lead bends.

It should be noted that the presence of body fluids decreases the intensity of adhesive wear of insulation external layer. The leads surrounded by tissues or immersed in body fluids meet the non-polymer friction partner i.e. soft tissues in the pocket, CID can, morphotic elements in the blood, and inner fragments of the cardiovascular system. It can be considered that this last mechanism of wet friction involves two physical processes simultaneously, i.e. directional micro-tearing and directionless micro-delaminating or polishing. Another special situation is adhesive and frictional 


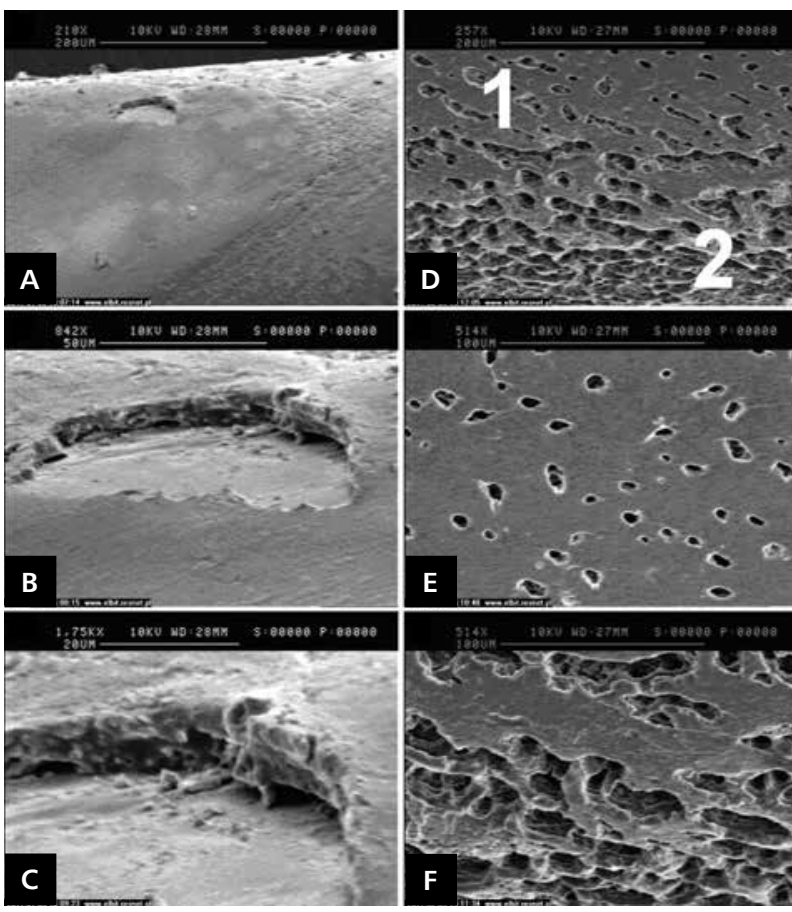

Figure 1. Bipolar active-fixation ventricular lead with eight-year dwell time in the BiA-V stimulation system. Indication for removal: lead-dependent infective endocarditis. Scanning electron microscopy images; A, B, C. Lead insulation wear with maintained integrity. Destruction at the level of the right atrium near the entrance to the tricuspid valve. At this point the lead was bending and rubbing against another lead implanted in the proximal coronary sinus; $\mathbf{A}$. Visible polishing of insulation surface resulting from friction contact. The formation of micro cracks under the surface of insulation resulted in separation of silicone from lead insulation. Progressive magnification of a single large area of silicone loss (A. 21.0 ; B. $842 \times$; C. $1750 \times$ ); D, E, F. Dropping out of silicone at the point of lead bending without friction against another lead. Multiple cavities in silicone (D. 25×; E. magnification 514× of area 1 ; F. magnification $514 \times$ of area 2 from Figure 1D)

contact between two leads covered by polymer insulation. In this situation, the friction partners are polymer and polymer, and friction wear occurs. In the case of silicone insulation, frictional wear of the elastomer takes place even when counter surfaces are smooth, because the frictional coefficient is large. Relative motion of tribological pair elements may result in rupture and tearing of silicone pieces and their detachment from the contact zone. Expulsion of the material from the friction zone, and probable removal to remote sites, e.g. towards the lungs, occurs when blood rinses this area. Displacement onto the counter silicone surface occurs within the CID pocket (Fig. 3). In these conditions, silicone debris may also appear on the border of the friction zone (Fig. 4). In the next stage of tribological destruction of silicone insulation there is abrasive wear caused by detachment of particles from the surface of polymer as the effect of fatigue

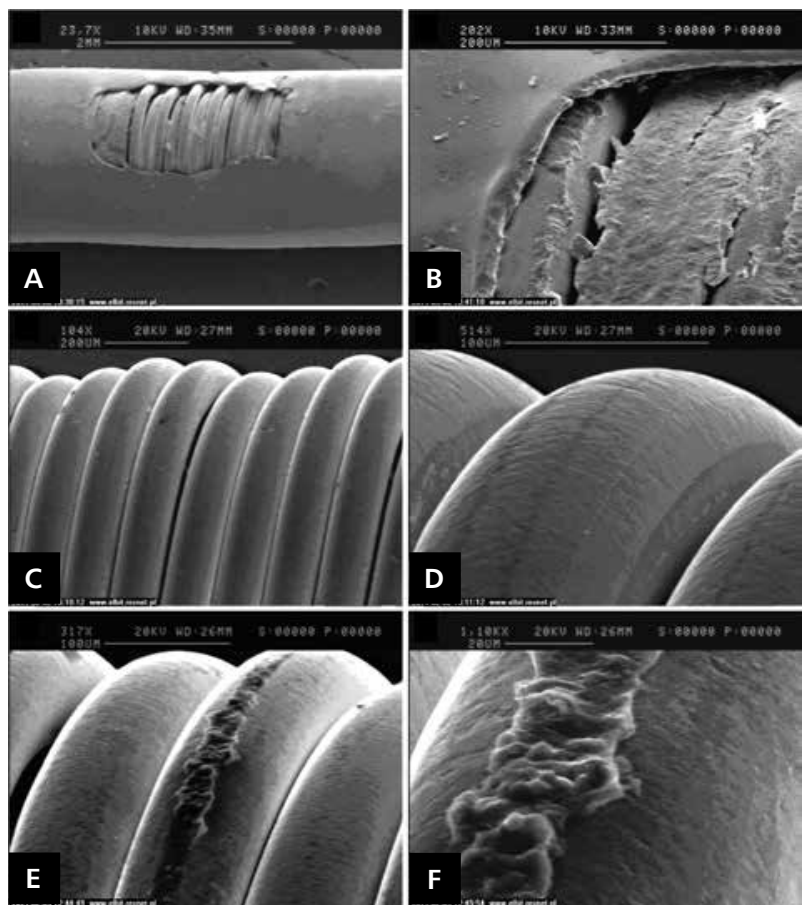

Figure 2. Bipolar passive-fixation ventricular lead with seven-year dwell time in the right ventricular apex. The lead had been inactive for three years, abandoned after replacement for an implantable cardioverter-defibrillator (ICD) lead. Cracked insulation at the level of the tricuspid valve, where the lead was bending and rubbing against the distal ICD coil. Indication for removal: lead-dependent infective endocarditis. Images of the surface of metal wires in new (C, D) and damaged (A, B, E, F) leads showing microscopic debris of silicone lead insulation on the metal wire; A, B. View of the totally worn out lead silicone insulation and shift of silicone on the metal wire visible in the abraded opening in the insulation under various magnifications: A. 23.7×; B. 202x;

C, D. Surfaces of the metal wire in a new lead (C. 104X,

D. $514 \times)$; E, F. The surface of the wire in the site with preserved insulation integrity - visible accumulation of silicone created by abrasion in internal insulation layer (E. 317×; F. 1,100×)

and adhesive wear, and the alteration of insulation surface from even to rough. Roughness of contact surfaces works as micro blades that cut and scratch lead insulation, causing a relatively fast loss of material [16]. Abrasive wear arises primarily from friction between the sliding surfaces of leads or leads and tissues. It is a process in which a harder partner in tribological pair presses the surface of the softer one, and ploughs a groove that results in the detachment of material pieces from the softer surface [12]. Sharp edges of surface defects and insulation roughness gradually peel off the face of the second lead. This mechanism is frequently referred to as 'two-body abrasion' and it occurs when one surface cuts material away from the other. Frictional abrasive wear results in progressive damage of the insulation from its thinning to breaking its integrity, and finally to exposing the metal wire and internal PM lead spaces (Fig. 5). 

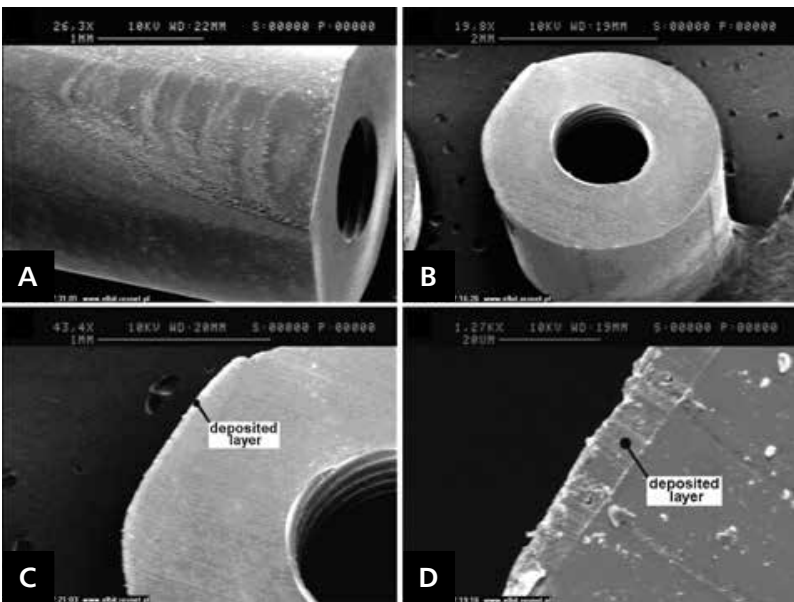

Figure 3. DDD pacing system with eight-year dwell time. One lead rubbed against the other in the pocket. Indication for removal: lead-dependent infective endocarditis. Scanning electron microscopy images. In polymer-polymer tribological pair transfer of material occurs from one lead insulation to another; A. A piece of cut insulation with an area of silicone deposit $(20.3 \times)$; B. Cross section of the silicone insulation clearly flattened on one side $(19.8 \times)$; C, D. Image of the deposited layer in the flattened site from Figure 3B (C. 43.4×; D. 1,270×)

\section{Summary}

The placing of a bundle of leads in the human body via the same channel triggers their tribological wear. Tribological wear occurs along the whole lead whenever it adheres to or slides along another body: valve apparatus, encapsulating tissue, device cans. The mechanism and rate of wear depend on several factors, the most important of which are: the number of leads, the method of their implantation, the spatial configuration both in the CID pocket as well as in the cardiovascular system, the dwell time in the human body, and the type of physical activity depending mainly on the patient's age and temperament.

A lead is structured as a set of two or more elements contacting on various surfaces. They are interacting sequentially or simultaneously with each other. Due to this fact, tribological wear can appear when the patient has only one lead and it bends at the level of the tricuspid valve, which has been recently described [17]. Damage to endocavitary leads is probably caused also by other tribological mechanisms, for example erosion or fretting. This requires further research.

Effect such as rupture and tearing of polymer pieces and their expulsion from the friction contact zone in the bloodstream differs from those in the CID pocket. It is also different at the interface between a metal wire and internal silicone insulation surface.

According to the concept of silicon insulation biodegradation with the participation of macrophages and multinuclear giant cells, it appears only in certain endocavitary lead fragments in vivo [18]. If biodegradation of polymer insulation was supposed to be the main or initial mechanism of damage,

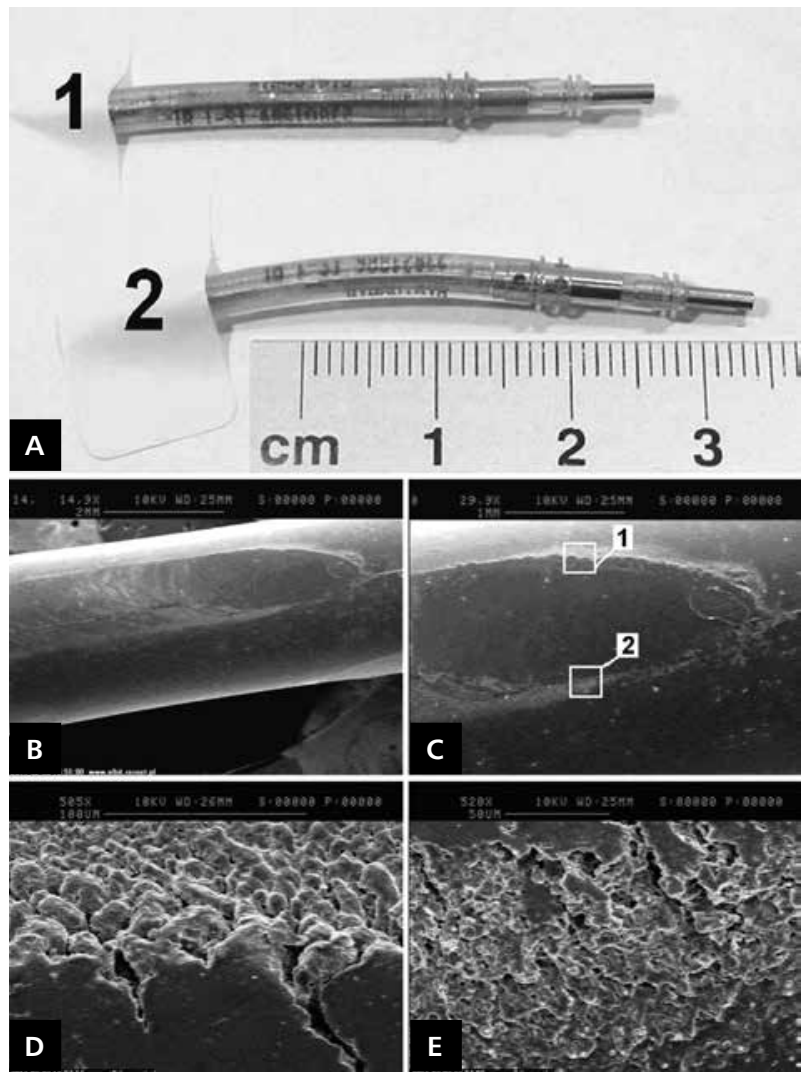

Figure 4. DDD system with ten-year dwell time, removed due to pocket infection. Images of expulsion of silicone torn away from friction zone and of silicone accumulation on the edges of the zone in the form of silicone growth; $\mathbf{A}$. Gross view of two abraded lead fragments in the mechanism of lead to lead friction in cardiac implantable device (CID) pocket, near CID can; B-E. Scanning electron microscopy images; B, C. Magnification of abrasion of lead number 1 from Figure 4A (B. 14.9x; C. $29.9 \times)$; D, E. Magnification of destruction of friction zone with its edges from Figure 4C; $\mathbf{D}$. Region 1 of the abrasion edge from Figure $4 C(505 \times)$; E. Region 2 of the abrasion edge from Figure $4 C(520 \times)$

it would be difficult to prove the reason for its local presence - not along the whole length and circumference of the lead. This limitation of damage to specific lead fragments finds justification in tribology. Activation of macrophages in the presence of silicone debris abraded in the tribological process is most probable.

Silicone lead wear is usually not the result of a single mechanism but of a combination of different mechanisms, including ageing of material. The present preliminary report does not claim to possess the right to discuss and provide proofs for existence of all silicone lead wear mechanisms. Damage to the silicone endocardial lead insulation leads to the loss of its evenness up to breakage, becoming an anchor for bacterial infection with the possibility of CID electrical dysfunction. This fact is extremely significant in clinical practice. 


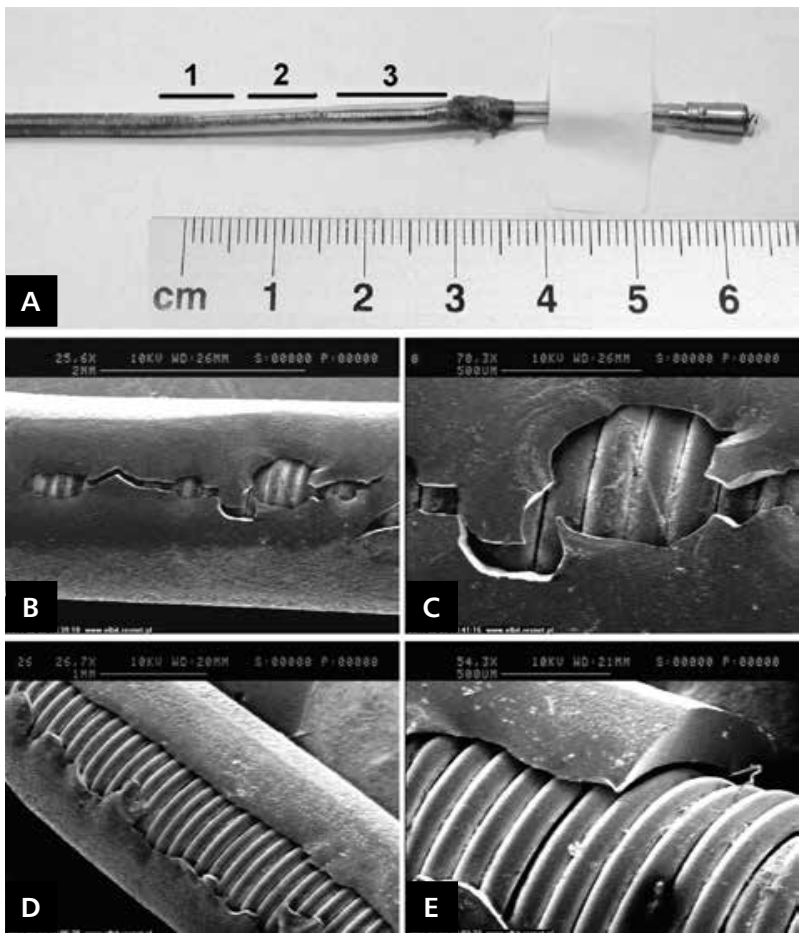

Figure 5. Bipolar active-fixation left atrial lead with eight-year dwell time in the proximal coronary sinus. Removed due to lead-dependent infective endocarditis. View of the surface of the totally abraded lead. Lead insulation was destroyed near the entrance to the coronary sinus in the area of the tricuspid valve where the lead was cyclically bending and rubbing on the right ventricular lead. A. Overview of three lead sections: 1, 2 and 3 with abrasion and cracks in silicone insulation; B-E. Scanning electron microscopy images (B, C. magnification of the first section shown in Figure 5A: B. 25.6x; C. $70.3 \times ; D, E$. magnification of the third section shown in Figure 5A: D. 26.7×; E. 54.3×); E. Cross section of the insulation - visible silicone loss i.e. gradual thinning of insulation up to its disappearance resulting in exposure of the metal wire

\section{CONCLUSIONS}

Tribological wear of implanted leads is a serious issue that elucidates the lack of durability of such cardiac implants. This is a challenge for the manufacturers of implantable PM and ICD.

\section{Conflict of interest: none declared}

\section{References}

1. Russo AM, Marchlinski FE. Engineering and constraction of pacemaker and implantable cardioverter-defibrillator leads. In: Ellenbogem KA, Kay GN, Lau C-P, Wilkoff B eds. Clinical cardiac pacing, defibrillation, and resynchronization therapy. Saunders, and imprint of Elsevier Inc, Philadelphia 2007: 161-200.

2. Jacobs DM, Fink AS, Miller RP et al. Anatomical and morphological evaluation of pacemaker lead compression. Pacing Clin. Electrophysiol, 1993; 16: 434-444.

3. Magney JE, Flynn DM, Parsons JA et al. Anatomical mechanisms explaining damage to pacemaker leads, defibrillator leads, and failure of central venous catheters adjacent to the sternoclavicular joint. Pacing Clin Electrophysiol, 1993; 16: 445-457.

4. Mehta D, Nayak HM, Singson M et al. Late complications in patients with pectoral defibrillator implants with transvenous defibrillator systems: high incidence of insulation breakdown. Pacing Clin. Electrophysiol, 1998; 21: 1893-1900.

5. Kołodzińska A, Kutarski A, Grabowski M et al. Abrasions of the outer silicone insulation of endocardial leads in their intracardiac part; a new mechanism of lead-dependent endocarditis. Europace, 2012; 14: 903-910.

6. Ząbek A, Małecka B, Kołodzińska A et al. Early abrasion of outer silicone insulation after intracardiac lead friction in a patient with cardiac device related infective endocarditis. Pacing Clin. Electrophysiol, 2012; 35: e156-e158.

7. Kutarski A, Małecka B. Przetarcie silikonowych izolacji elektrod wewnątrzsercowych - nowo odkryte zjawisko w elektroterapii: obserwacje własne. Folia Cardiol Excerpta, 2009; 4: 126-131.

8. Jost P. Lubrication (Tribology), education and research. A report of the present position and industry's needs. Deptartment of Education and Science, The Majesty's Station Office. London, 1966.

9. Kutarski A, Małecka B, Kołodzińska A, Grabowski M. Mutual abrasion of endocardial leads: analysis of explanted leads. Pacing Clin. Electrophysiol, 2013; 36: 1503-1511.

10. Colas A, Curtis J. Silicone biomaterials: history and chemistry. In: Ratner BD, Hoffman AS, Schoen FJ, Lemons JE eds. Biomaterial Science. An Introduction to Materials in Medicine. Elsevier Academic Press, San Diego, CA 2004: 80-86.

11. Rymuza Z: Tribology of polymers. Archives Civil Mech Engineering, 2007; 7: 177-184.

12. Zhang SW. State-of-the-art of polymer tribology. Tribology International, 1998; 31: 49-60.

13. Zhang SW. State-of-the-art of rubber tribology. Polymer tribology: 312-343. In: Sujeet K, Briscoe BJ eds. Polymer tribology. Imperial College Press, 2009.

14. Brostow W, Kovačević V, Vrsaljko D, Whitworth J. Tribology of polymers and polymer — based composites. J Materials Education, 2010; 32: 273-290.

15. Kha HN, Chen BK. Determination of frictional conditions between electrode array and endosteum lining for use in cochlear implant models. J Biomechanics, 2006; 39: 1752-1756.

16. Schwartz CJ, Bahadur S. Development and testing of a novel joint wear simulator and investigation of the viability of an elastomeric polyurethane for total-joint arthroplasty devices. Wear, 2007; 262: 331-339.

17. Małecka B, Rydlewska A, Ząbek A et al. Intracardiac damage of silicone insulation of a single lead and infective endocarditis. Kardiol Pol, 2013; 71: 1095.

18. Kołodzińska A, Kutarski A, Kozłowska M et al. Biodegradation of the outer silicone insulation of endocardial leads. Circ Arrhythm Electrophysiol, 2013; 6: 279-286. 


\title{
Przetarcie silikonowych elektrod endokawitarnych: opis zjawisk trybologicznych na podstawie badań mikroskopowych usuniętych elektrod. Doniesienie wstępne
}

\author{
Barbara Małecka ${ }^{1}$, Andrzej Ząbek ${ }^{2}$, Andrzej Ciaś3 ${ }^{3}$, Janusz Stępiński ${ }^{3}$, Andrzej Kutarski ${ }^{4}$, Jacek Rońda ${ }^{5}$, \\ Jacek Lelakowski ${ }^{1}$, Janusz Małecki ${ }^{6}$ \\ ${ }^{1}$ Klinika Elektrokardiologii, Instytut Kardiologii, Uniwersytet Jagielloński, Collegium Medicum, Krakowski Szpital Specjalistyczny \\ im. Jana Pawła II, Kraków \\ ${ }^{2}$ Kliniczny Oddział Elektrokardiologii, Krakowski Szpital Specjalistyczny im. Jana Pawła II, Kraków \\ ${ }^{3}$ Wydział Inżynierii Metali i Informatyki Przemysłowej, Katedra Metaloznawstwa i Metalurgii Proszków, Akademia Górniczo-Hutnicza \\ im. Stanisława Staszica, Kraków \\ ${ }^{4}$ Klinika Kardiologii, Uniwersytet Medyczny, Lublin \\ ${ }^{5}$ Wydział Inżynierii Metali i Informatyki Przemysłowej, Katedra Informatyki Stosowanej i Modelowania, Akademia Górniczo-Hutnicza \\ im. Stanisława Staszica, Kraków \\ ${ }^{6}$ Indywidualna Specjalistyczna Praktyka Lekarska, Kraków
}

\section{Streszczen i e}

Wstęp: Elektrody endokawitarne są zbudowane z metalowych przewodów umieszczonych wewnątrz polimerowych rurek pełniących funkcję izolacji. Ich wzajemny kontakt w układzie sercowo-naczyniowym, wykonywane ruchy z częstością rytmu serca oraz oddziaływanie okolicznych tkanek powodują ich zużycie. Przebieg elektrod endokawitarnych w okolicy podobojczykowej i w obrębie układu sercowo-naczyniowego zależy od techniki implantacji. Wpływa to na możliwość późniejszego uszkodzenia elektrod. Przerwanie zewnętrznej osłony elektrod stymulatorowych staje się punktem zaczepienia odelektrodowego zapalenia wsierdzia. Odsłonięcie przewodów w elektrodach kardiowerterowych/defibrylatorowych doprowadza do nieadekwatnych interwencji urządzenia.

Cel: Celem pracy było opisanie przetarć elektrod endokawitarnych wg reguł mechaniki. Zjawiska trybologiczne zostały ukazane w przypadku tarcia polimeru o polimer, kiedy elektroda pętli się i/lub trze o inną elektrodę, oraz wewnątrz strukturalnej konstrukcji elektrody, kiedy tarcie zachodzi między osłoną polimerową a metalowym przewodem.

Metody: U 10 pacjentów (3 kobiety) w wieku 66,5 \pm 13,4 roku zostały usunięte 22 elektrody endokawitarne. Powodem usunięcia we wszystkich przypadkach były powikłania infekcyjne (w 80\% LDIE). Usuwane układy składały się z 2 lub 3 elektrod i pozostawały w ludzkim ciele 3-25 lat (śr. 8,3 roku). Wszystkie badane elektrody miały osłonę silikonową. Przeprowadzono mikroskopowe badanie usuniętych elektrod w mikroskopie optycznym i mikroskopie skaningowym. Miejsca uszkodzeń były oznaczane jako odległość od dystalnego końca elektrod. W skopii RTG zarejestrowanej przed zabiegiem usuwania analizowano lokalizację i rodzaj ruchu, jaki wykonywały uszkodzone fragmenty elektrod. W ten sposób wyróżniono 3 rejony, w których dochodziło do uszkodzeń elektrod: wewnątrz jam serca, wewnątrz żył doprowadzających do serca i wewnątrz loży urządzenia. Obrazy trybologicznego zużycia materiału, z którego wykonano elektrody, rejestrowano w dwóch obszarach: wewnątrz elektrody, na styku między polimerem i metalem oraz między elektrodami. Rejestrowano następujące dane: rodzaj systemu stymulacji lub kardiowersji/defibrylacji, z którego pochodziły usunięte elektrody, czas przebywania elektrod w ciele i model elektrod.

Wyniki: Analiza zdjęć z mikroskopu skaningowego wykazała, że silikonowa izolacja ulegała trybologicznemu zużyciu w przypadku wszystkich zbadanych elektrod. U 80\% pacjentów (z LDIE) wykazano całkowite przerwanie ciągłości silikonowej zewnętrznej izolacji z odsłonięciem metalowego przewodu i wewnętrznych przestrzeni elektrody w obrębie jam serca. Początkowym etapem 
trybologicznego niszczenia elektrody jest zużycie zmęczeniowe i adhezyjne. Zużywanie zmęczeniowe jest spowodowane przez cyklicznie zmienne odkształcenia warstwy wierzchniej. Wskutek tych zmiennych, ale cyklicznych obciążeń pod powierzchnią osłonki, w tzw. punktach Bielajewa, powstają mikropęknięcia, których postępowanie ku powierzchni, dalszy rozwój i łączenie powoduje wykruszanie się materiału. Zużycie zmęczeniowe silikonu pojawia się również wtedy, gdy powierzchnia jest gładka i może wystąpić we wszystkich odcinkach osłonki silikonowej poddawanych uginaniu, nawet jeżeli nie wchodzą one w kontakt z powierzchnią otaczających tkanek, elementów innej elektrody lub puszki urządzenia wszczepialnego. Zużycie adhezyjne wiąże się z adhezją, czyli przyleganiem powierzchni trących. Powoduje to lokalne sczepienia tych powierzchni, co jest powodem pękania wiązań kohezyjnych. Obecność płynów ustrojowych osłabia intensywność zużycia adhezyjnego. Zjawiskiem szczególnym jest to, że również wewnętrzna strona osłony silikonowej podczas uginania ociera się o metalowy przewód elektrody, tworząc parę cierną polimer/niepolimer. To połączenie jest obecne na całej długości elektrody. Sczepienie adhezyjne powierzchni trących wywołuje lokalne plastyczne odkształcenie materiału, pękanie wiązań kohezyjnych, prowadząc do przenoszenia materiału na przeciwpróbkę. W niniejszej pracy stwierdzono przeniesienie mikroskopijnych fragmentów wewnętrznej części osłony na metalowy przewód. W parach polimer-polimer (elektroda-elektroda) intensywne przenoszenie materiału może występować w kierunku obu współpracujących powierzchni. Kiedy elektrody przewlekle trą się o siebie i tracą swoją fabryczną gładkość w wyniku inkubacyjnego zużycia zmęczeniowego i adhezyjnego, rozpoczyna się zużycie ścierne, przyspieszając ubytek materiału z osłony polimerowej z następowym rozszczelnieniem elektrody.

Wnioski: Niszczenie elektrod endokawitarnych w mechanizmie trybologicznym tłumaczy zarówno powszechnie znany „,zespół zmiażdżenia" pod obojczykiem, otarcia elektrod w loży urządzenia wszczepialnego, jak i opisane ostatnio przetarcia elektrod wewnątrz układu sercowo-naczyniowego.

Słowa kluczowe: elektrody endokawitarne, zużycie trybologiczne, izolacja silikonowa

W dniu 6 października 2014 roku nominację profesorską z rąk Prezydenta RP Bronisława Komorowskiego otrzymali następujący kardiolodzy, współautorzy i recenzenci prac publikowanych na łamach naszego pisma:

Prof. dr hab. n. med. Waldemar Bobkowski

(Uniwersytet Medyczny w Poznaniu)

Prof. dr hab. n. med. Jerzy Gąsowski

(Collegium Medicum Uniwersytetu Jagiellońskiego w Krakowie)

Panom Profesorom

serdeczne gratulacje i okolicznościowe życzenia składają:

Redaktor Naczelny oraz Rada Redakcyjna i Naukowa „Kardiologii Polskiej” 